\title{
MAP OF IMPACT OF NATURAL HAZARDS
}

\author{
Bostenaru Dan, Maria ${ }^{1,2}$ \\ Gociman, Cristina Olga ${ }^{3}$ \\ ${ }^{1}$ Accademia di Romania a Roma \\ maria.bostenaru@iaim.ro \\ ${ }^{2}$ University of Bucharest \\ Maria.Bostenaru-Dan@alumni.uni-karlsruhe.de \\ 3 "Ion Mincu" University of Architecture and Urban Planning \\ criba proiectare@yahoo.com
}

Abstract. This paper investigates the mapping of the impact of natural hazards as included in several databases reviewed or created by the author. These are:

- The database of the contribution of the session series "Natural hazards' impact on urban areas and infrastructure", convened and co-convened by the first author over 15 years at the European Geosciences General Assembly.

- A database created from reviews of students supervised by the authors in frame of the course "Protection of settlements against risks" at the home university.

- A collection of historical photographs from the 19th century on different natural and man-made hazards from the Canadian Centre for Architecture, the archive review of which has been performed by the first author and which will be subject of a book to be published about the time of the conference.

-Two reviewed collections, one from the exhibition and book on "Images of disasters" (German research) and one on the book "Illustrated history of natural disasters" which include major disasters from the beginning of the mankind.

In frame of the paper maps of the spread of data will be presented, created using both arcGIS online and GoogleMaps (see https://www.google.com/maps/d/edit?mid=zpbbz3WgVMBs.k-3vhGj-11M\&usp=sharing), comparing the source and the type of hazard, to see eventual overlappings between the databases.

Keywords. map, natural hazard, database, impact, archive, historical

\section{Introduction}

Ruins of disasters are ruins of the moment, said Constanze Baum [1]. They are created by a disaster in a moment, and removed during reconstruction efforts. Exceptions include monuments such as the Carmo Convent in Lisbon. However, 
images are kept, and they form valuable databases of the impact of disasters. Recently, the DESURBS European project created a database of security incidents [2] from recent times. The data has been prepared to be entered into the DESURBS database, should it grow to a voluntary project similar to the World Housing Encyclopedia [3].

\section{European Geosciences Union Session "Natural hazards' impact on urban areas and infrastructure"}

The format of the European Geosciences Union general assemblies, and its predecessor European Geophysical Society provided a call for sessions from the scientific community. In this frame from 1999 on a session on the topic "Natural hazards' impact on urban areas and infrastructure" was proposed and was successful ever since. The first proposer was Friedemann Wenzel from the then University of Karlsruhe. Since 2002 it was taken over by Maria Bostenaru Dan, till 2010, who is since then co-convener. An article was published with the overview from the begin till 2010 [4], which includes also the publications resulting from the session, since for this the frame is not given by the conference, but relies on the initiative of the session organizers. The paper [4] gives some statistics, but it is first this paper giving an overview of the case studies covered with their geographical spread, following the comments in 2015. This is presented in Fig. 1. Tab. 1 gives the row data with which it was worked, as the georeferencing was done for all kinds of geographic features, such as mountains, rivers, localities, countries, regions. For this arcGIS online was employed. The method was used also for the subsequent maps in the other sections. The row data resulted from the titles and abstracts of the section, which are not all archived online, but exist also as Macromedia CD ROMs as in the 2000s. For his analysis only the location and the type of hazard were considered, not also the time it took place. In a further development we aim to include the time frame like in the DESURBS project. It is important to note that the data refers to the "impact" as such, which was rarely covered till now, and thus a valuable database. Not all papers in the session were case studies though, some of them dealing with general methodologies, and as such the geographic link was not always easy to be located if it could be at all. Some of them covered multi-hazard also. We considered here the main hazard associated in this case. To enrich the collection on impact, we considered a number of other databases as we will see.

\section{Images of disasters}

D17 Images of Disasters was a project in the field of history and heritage at the Cluster Asia and Europe at the University of Heidelberg under the leadership of Gerrit Jasper Schenk from the Technical University of Darmstadt. Following an international conference in 2012, in 2014-15 an exhibition was organized at the Reiss Engelhorn Museum. The exhibition was accompanied by a catalogue [5], which we reviewed and mapped the disasters. In case of this collection, unlike the previous one the time span is much larger, starting with disasters which took place in antiquity, some of them legendary. The exhibition presented media images: 
drawings, photography, films, but also literary and other art works (anime, opera) inspired by the disasters, from antiquity till today, with Tohoku earthquake and tsunami and climate change. Fig. 2 presents a mapping of these disasters. In the book [5] both the media but also the geophysical background to the disasters are explained.

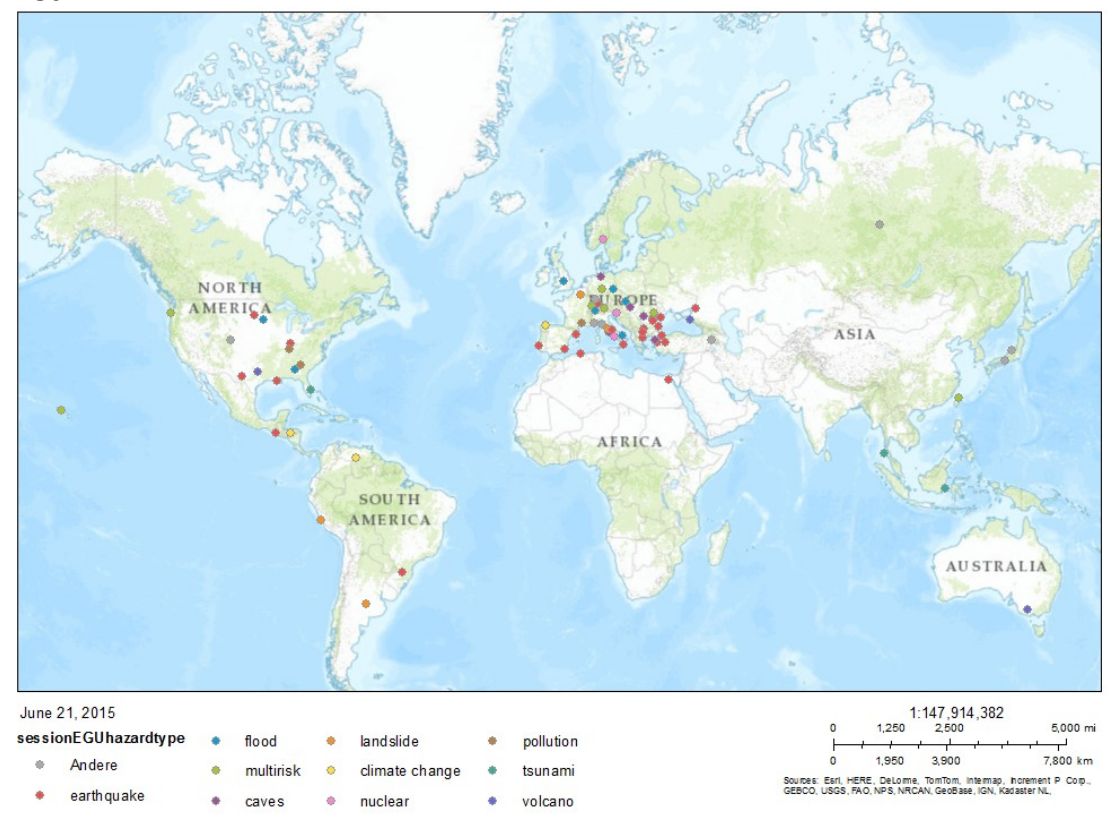

Fig. 1 Mapping of the case studies covered by the papers presented in the session "Natural Hazards' Impact on Urban Areas and Infrastructure" at the European Geosciences Union general assembly, by type

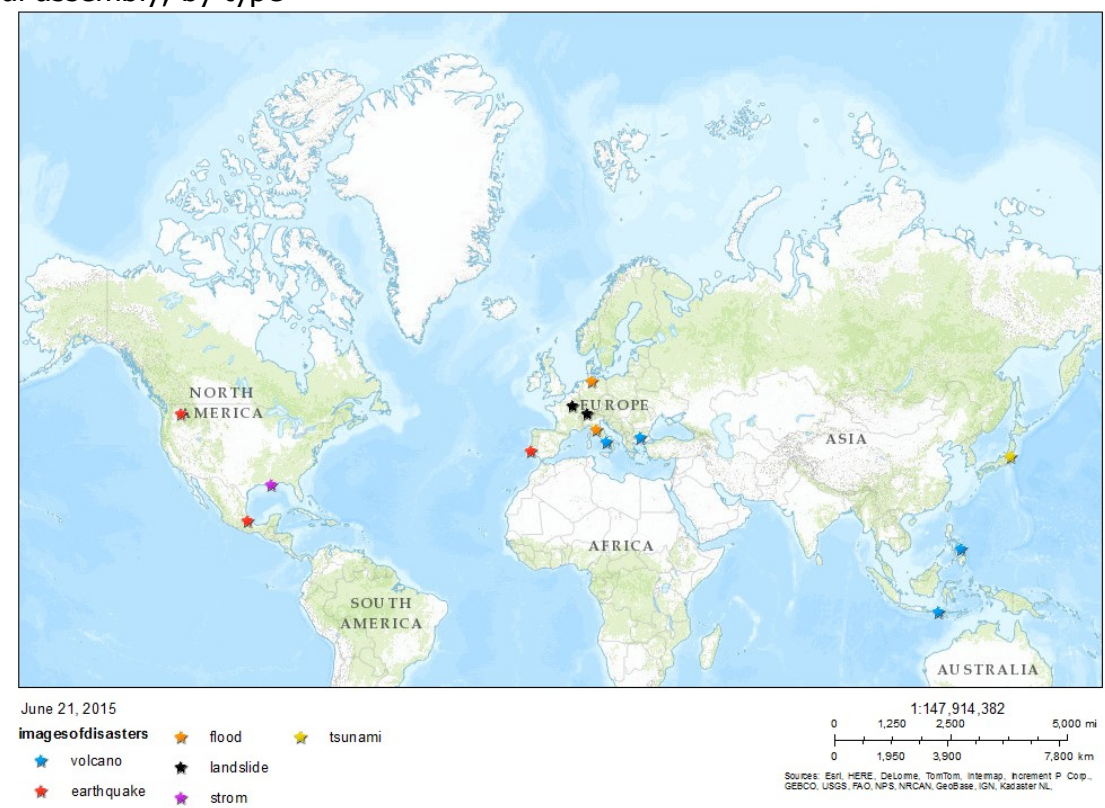

Fig. 2 Map of the disasters covered by the exhibition "Mensch. Natur. Katastrophe" (Men, Nature, Disaster) in REM Mannheim, as a result of the "Images of disasters" project in Heidelberg 
Tab. 1 Table of the disasters covered by the papers presented in the session "Natural Hazards' Impact on Urban Areas and Infrastructure" at the European Geosciences Union general assembly, by type

\begin{tabular}{|c|c|c|c|}
\hline location & type & location & type \\
\hline Cairo & earthquake & Hamburg & caves \\
\hline Inca & landslide & Murge (Apulia), Italy & precipitation \\
\hline Dresden/Sachsen & flood & Andes, South America & landslide \\
\hline Oslo & nuclear & Germany & multirisk \\
\hline Kocaeli & earthquake & Napoli & caves \\
\hline Japan & frost & Murcia, Spain & earthquake \\
\hline Mazou (Zagros) Iran & landslide & Hungarian Danube & flood \\
\hline Boumerdes, Algeria & earthquake & Nankai, Japan & earthquake \\
\hline Bam, Iran & earthquake & Russian federation & transport \\
\hline Himalaya & earthquake & Bari, Italy & flood \\
\hline Borst, Zirovski & nuclear & Northern Caucases & landslides \\
\hline Albstadt, Germany & earthquake & Kutahya, Turkey & earthquake \\
\hline Thessaloniki, Greece & earthquake & Rhine-Maine Area & precipitation \\
\hline Sofia, Bulgaria & earthquake & Kilimli (Zonguldak) & caves \\
\hline NE Romania & earthquake & Petrosani & caves \\
\hline Rostov-on-Don & earthquake & Taipei & multirisk \\
\hline Yerevan & & Galicia, Spain & climate change \\
\hline Bucharest, Romania & earthquake & Targu Ocna & multirisk \\
\hline Istanbul & earthquake & Kamchatka & volcano \\
\hline Gees Maar (West Eifel), Germany & volcano & Trento, Adige river, Italy & flood \\
\hline Barcelona & earthquake & Chichi, Taiwan & earthquake \\
\hline Crotone, Italy & earthquake & Vesuvius, Italy & volcano \\
\hline Mulhouse, France & multirisk & Pisa, Italy & liquefaction \\
\hline Athens & pollution & Bucharest, Romania & earthquake \\
\hline N Africa & pollution & Honc & climate change \\
\hline Kyoto & & Venezuela & climate change \\
\hline Motril city, Spain & earthquake & Sofia, Plovdiv, Varna, Bulgaria & earthquake \\
\hline center-east Iran & earthquake & $\begin{array}{l}\text { Turnovo, and Blagoevgrad, } \\
\text { Bulgaria }\end{array}$ & earthquake \\
\hline Rome, Italy & caves & Napoli, Italy & nuclear \\
\hline Indonesia & tsunami & UK & flood \\
\hline Gastein valley, Austria & multirisk & Ionian Calabria & precipitation \\
\hline Karaj & flood & Switzerland & flood \\
\hline Indian ocean & tsunami & Hawaii & multirisk \\
\hline Jifara plain Basin, Libya & South Tirol & multirisk & \\
\hline Budapest & caves & Prahova Valley & flood \\
\hline Lisbon & earthquake & Karlsruhe & storm \\
\hline Phang Nga, Thai & tsunami & ash damps Romania & pollution \\
\hline Italy & landslide & Tulcea, Romania & earthquake \\
\hline L'Aquila & earthquake & Ploiesti, Romania & earthquake \\
\hline
\end{tabular}

\section{Illustrated history of natural disasters}

The "Illustrated history of natural disasters" [6] is a book only. Its images, also ranging from antiquity to today cover only earthquakes and volcano eruptions as depicted in mostly drawings from the collection of Jan Kozak. The accent here lies on the geophysical basics for these two related phenomena. Fig. 3. presents a map of the events covered. The transition to the next section is given by that we aim to do the same with early 19th century photography, posterior to drawings, to present the illustration of ruins and nature causing destruction. 


\section{Canadian Centre of Architecture Archive}

The Canadian Centre of Architecture in Montreal is a unique institution hosting all kinds of materials related to the built environment. These include photography of the impact of catastrophes on the built environment, such as ruins but not only, since it also includes high levels of water for flood or emergency efforts of providing tent cities after a disaster.

In our research we focused on fire, flood and earthquake, so both natural and man-made disasters. Other man-made disasters such as armed conflict (the Paris Commune or the effect of WWII on Cologne in the photography of August Sander) were also included. Giorgio Sommer has instead photography of volcano eruption, though not as rich as it can be found in commons. Other architectural photography archives do not have such a wealth of historic photography, and for this reason we searched in the Getty library and in the ICCROM library. From this point of view the CCA is unique. A further research on this database will include apart of mapping also the application of an ontology for classifying the photography [7], converted into the ORA Network approach. For setting in context the representation of ruin landscape was investigated [8], from the Romanticism till today, as well as literature on 19th century photography from which period most of those covered by the archive is [9].

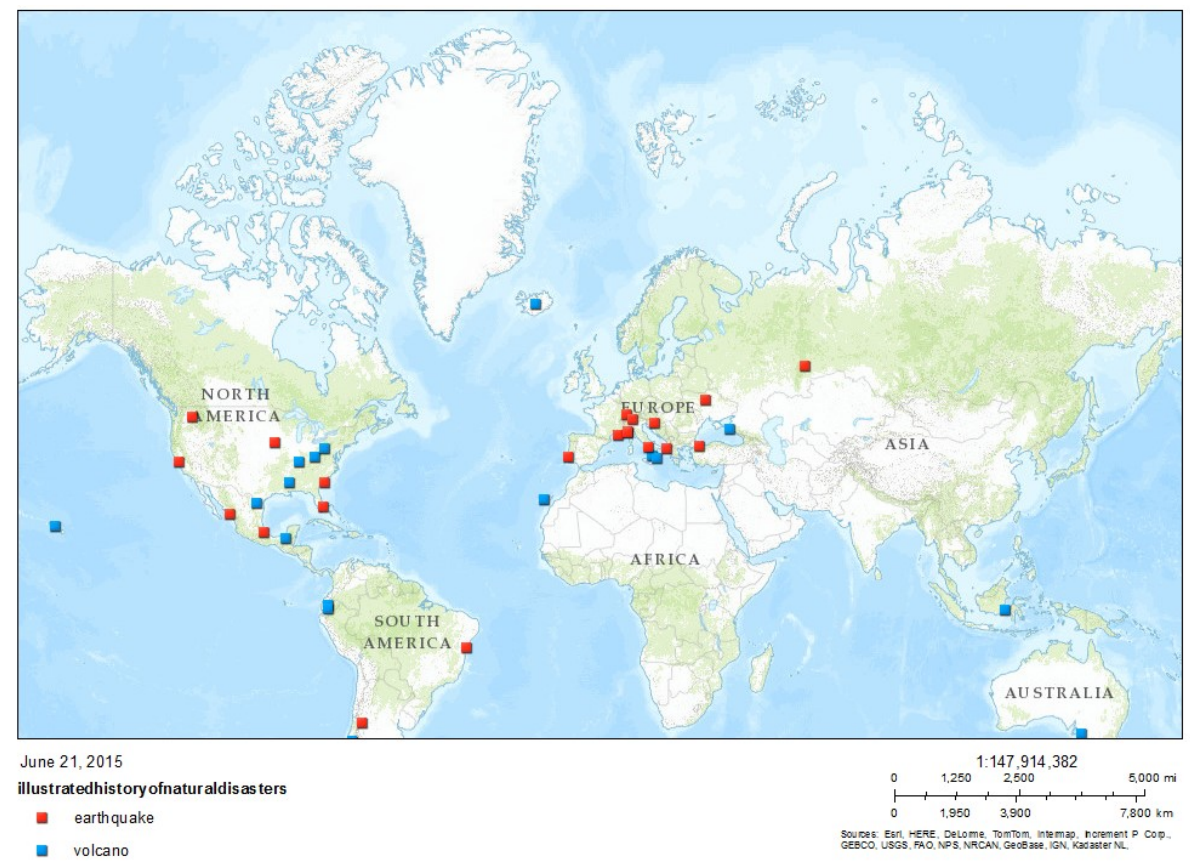

Fig. 3 Map of the disasters covered by the book "Illustrated history of natural disasters" by type

Also [10] offers a good overview on how images of catastrophes can be interpreted, considering also the philosophy currents in which this can be set. Thus the investigation brings together the natural sciences basics as in "Illustrated history of natural disasters" and the humanities approach as in "Images of disasters". Fig. 4 shows a map with the disasters for which images where 
consulted in the CCA database.

\section{Essays by Students}

Bringing over research results to teaching through involvement of students into research was one of the aims of the authors. The master "Urban design" at the "Ion Mincu" University of Architecture and Urbanism offers a course on "Protecting localities against risks". In frame of the course the students first get acquainted with different types of disasters, classified, then after this first part is concluded, have to write and present an essay for a chosen case study of a hazard.

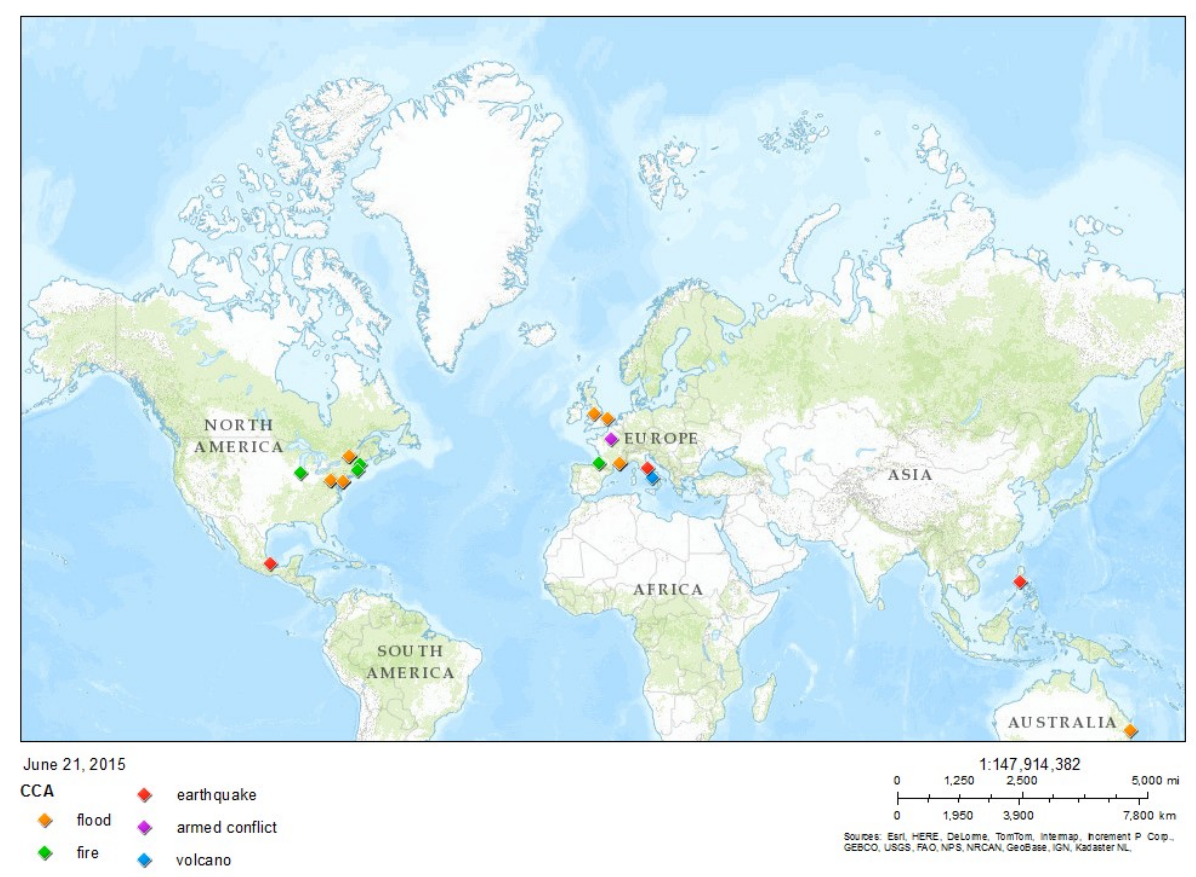

Fig. 4 Map of the disasters for which images exist and were investigated in the Canadian Centre for Architecture archive, by type.

For the final grade then they elaborate a project for a multi-hazard site in the city of Bucharest where the university is located, on the basis of further disaster management courses. The case study essays were archived and mapped in Fig. 5. These are most of the time, but not always, from the close past. There in an accent on the urban planning aspects, meaning what urban planning measures can be taken to manage the disaster should it occur again, and from this point of view they relate to the approach in DESURBS, which developed though IT tools and not built environment tools for this. This way, the approach is close to relating to the impact we aimed also in the session. 


\section{Overview of All Disasters}

The aim of this research was to enrich the database from the session run more than 15 years long in order to collect case study research on the impact of natural hazards.

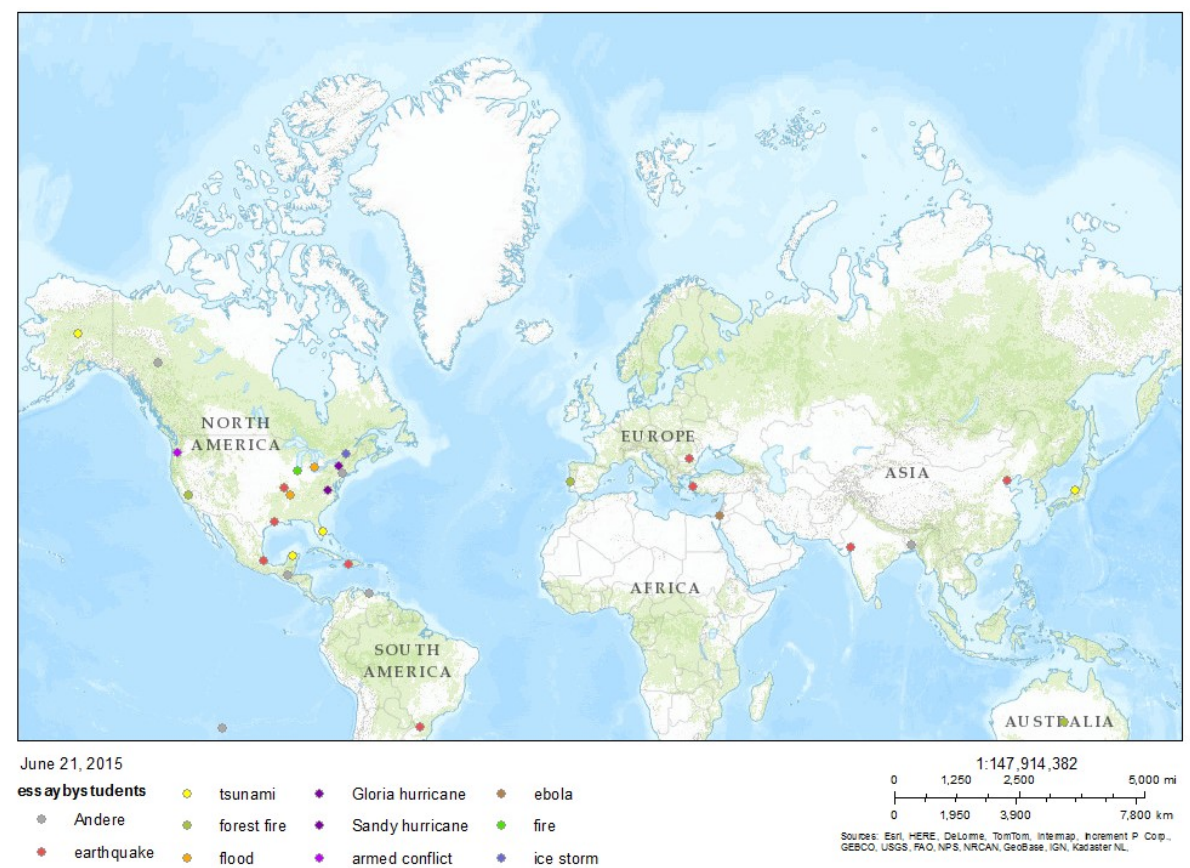

Fig. 5 Map of the disasters for which essays were prepared in the course taught to students.

If in the session there were more contemporary hazards (sometimes featuring the most recent strong one, for example in the case of the Bam earthquake, which made it in the press room session), in the databases based on books and on the archive, historical disasters were covered. This is an enrichment to what the DESURBS security incident database can offer. The student essays was also a directed initiative like the session call for papers. Fig. 6 shows an overview of all cases for which case study reports are available. These range from short abstracts in case of the session, sometimes accompanied by a full paper, to the essays of students which need review, over essays in books. For the archive images at the CCA this information has to be first compiled. The information has however a resolution high enough for the database of DESURBS and it would be helpful to extend the time range by merging and allowing for growth like in the World Housing Encyclopedia.

Fig. 6 shows an overview of all disasters covered. Remarkable is the geographic spread all over the world, in all databases. The colour and shape code is given in the legend. 


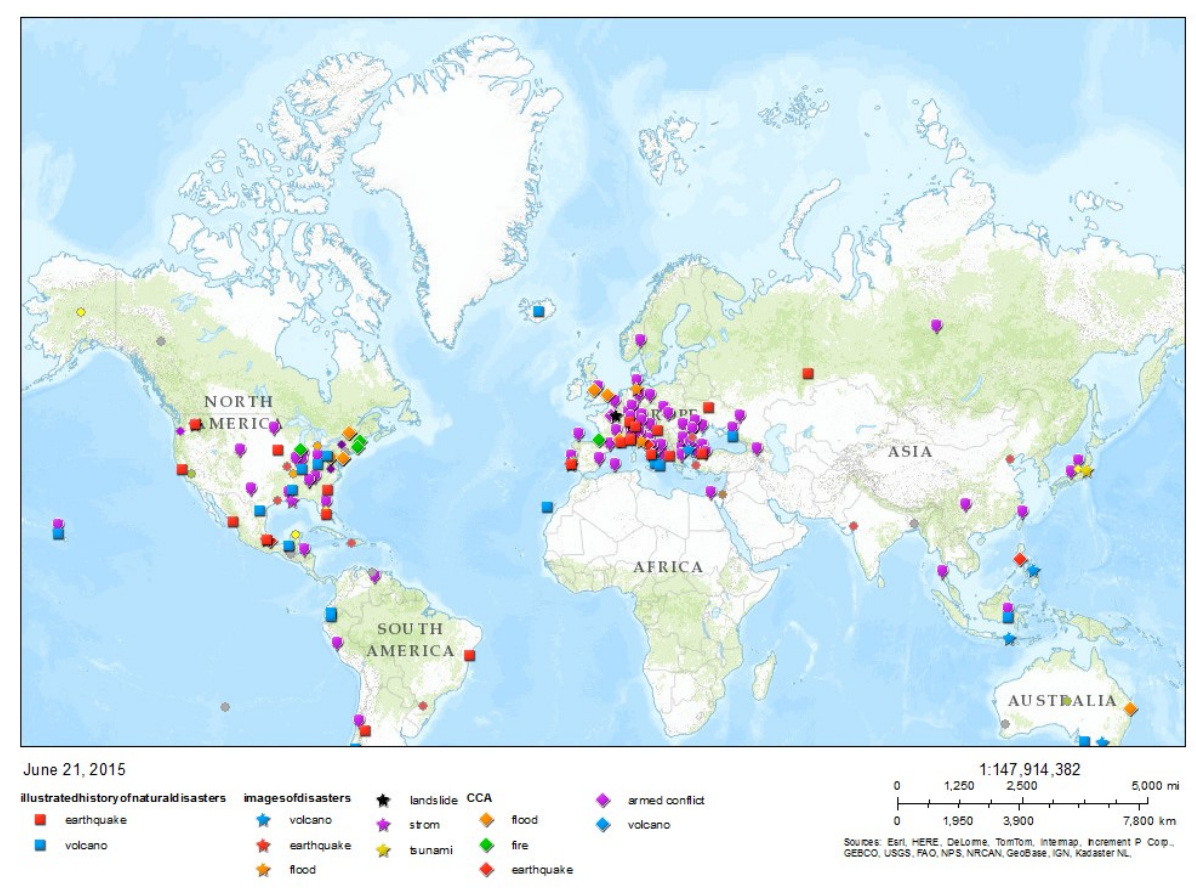

Fig. 6 Overview map of all disasters covered by different databases. For the various databases different shapes were chosen, while for a certain type of disaster the colour is unitary.

The mapping approach shown enforces how GIS can contribute to risk monitoring and thus to management of cultural resources. It is also an idea of how tools can be brought together to share knowledge and data from information collected similarly to volunteered geographic information way.

\section{Acknowledgements}

The first author would like to acknowledge the support of Prof. Dr. Friedemann Wenzel who started the session series at the EGU and from whom it was taken over during the first stay at the University of Karlsruhe. The paper was prepared in frame of the postdoctoral scholarship POSDRU 133391 which provided a a stage at the Karlsruhe Institute of Technology to Prof. Wenzel. The visit to the REM exhibition was also funded from POSDRU funds. The paper further features work done together with the second author in the course on "Protection of settlements against risks" who is the mentor for a postdoc at the Romanian School in Rome, for which the Vasile Pârvan scholarship is acknowledged. Further, the database of the Canadian Centre of Architecture was investigated with a support grant. 


\section{References}

[1] Baum, C., 2008. Ruinen des Augenblicks. Die bildliche Repräsentation des Erdbebens von Lissabon im Kontext eines Ruinendiskurses im 18. Jahrhundert, in Lauer, G. and Unger, T. (eds.): Das Erdbeben von Lissabon und der Katastrophendiskurs im 18. Jahrhundert, Wallstein, Göttingen.

[2] DESURBS | Designing Safer Urban Spaces http://desurbs.eu/

[3] Brzev, S., Greene, M., 2004. World Housing Encyclopedia - summary, EERI, Oakland.

[4] Bostenaru Dan, M. 2011. The session series on "Natural Hazards' impact on urban areas and infrastructure", Reviews in Environmental Science and Bio/Technology, 10 (1) 9-24

[5] Wieczorek, A., Schenk, G. J., Juneja, M., Lind, C. (eds.), 2014. Mensch . Natur . Katastrophe: Von Atlantis bis heute, Reiss-Engelhorn-Museen, Schnell \& Steiner, Mannheim.

[6] Kozák, J., Cermák, V., 2010. The Illustrated History of Natural Disasters, Springer, Dordrecht.

[7] Bostenaru Dan, M., 2011. The use of ontology for digital conservation of architecture works after catastrophes, Journal of Applied Engineering Sciences, 1/14 (2) 11-18

[8] Conţu, M., 2013. Ziduri. Gânduri. Zvonuri. Şoapte. Povestea ruinei, arhitext 1/2013

[9] Hannavy, J. (ed.), 2008. Encyclopedia of nineteenth-century photography, Taylor \& Francis Group, New York ; London.

[10] Le Roy, F., Wynants, N., Hoens, D., Vanderbeeken, R., 2011. Tickle Your Catastrophe! Imagining Catastrophe in Art, Architecture and Philosophy, Academia Press, Ghent.

Article distributed under a Creative Commons Attribution-

NonCommercial-NoDerivatives 4.0 International License (CC BY-NC-ND).

Received February 23, 2016

Accepted March 24, 2016 